\title{
Koleksi surat kabar langka Perpustakaan Nasional Republik Indonesia sebagai sumber penelitian sejarah global
}

\author{
Frial Ramadhan Supratman \\ Perpustakaan Nasional Republik Indonesia \\ Jl. Salemba Raya No. 28 A, Senen, Jakarta Pusat, DKI Jakarta, 13140 \\ Email: frial_ramadhan@perpusnas.go.id
}

Received: December 2019; Accepted: May 2020; Published: June 2020

\begin{abstract}
Rare newspapers are one of the primary sources that can be used in historical research. Historians often use newspapers as a source of research. Therefore historians often come to the National Library of the Republic of Indonesia to conduct consultations on newspaper collections. Librarians should help historians find this main source. Thus, this research explains how the rare newspaper collection can be useful for historians in researching global history. The method used in this paper was descriptive qualitative. This method conducted a description and analysis to a research object, where the researcher a qualitative analysis of the research object. This study surveyed ten newspapers and sorted them into six papers, which were then analyzed. From the study results, the authors found that six rare newspapers in the National Library of the Republic of Indonesia could be used as a primary source in researching global history. The six papers were 'Oetoesan Hindia', 'Pancaran Warta', 'Keng Po', 'Warta Hindia', 'Pemandangan', and 'Soeara Oemoem.' The conclusions of this research are; first, newspapers can be used as a primary source of global history because they contain writings that respond to global dynamics. Second, criteria for newspapers that can be used as a source of global history research are those that provide information and opinions on global developments.
\end{abstract}

Keywords: Rare newspapers; National Library of the Republic of Indonesia; Primary sources; Global history

\begin{abstract}
Abstrak
Surat kabar langka merupakan salah satu sumber primer yang dapat digunakan dalam penelitian sejarah. Para sejarawan seringkali memanfaatkan surat kabar sebagai sumber penelitian. Untuk itu, para sejarawan sering datang ke Perpustakaan Nasional Republik Indonesia untuk melakukan konsultasi mengenai koleksi surat kabar. Pustakawan seharusnya dapat membantu para sejarawan dalam menemukan sumber primer ini. Tujuan penelitian ini adalah bagaimana koleksi surat kabar langka dapat bermanfaat untuk para sejarawan dalam meneliti sejarah global. Penelitian ini menggunakan metode deskriptif kualitatif. Metode ini mencoba melakukan deskripsi dan analisis terhadap suatu objek penelitian, di mana peneliti melakukan analisis kualitatif terhadap objek penelitian. Penelitian ini dilakukan dengan cara mengambil survei sepuluh surat kabar dan memilahnya menjadi enam surat kabar kemudian dianalisis. Hasil dari penelitian ini adalah bahwa penulis menemukan adanya enam surat kabar langka koleksi Perpustakaan Nasional Republik Indonesia yang dapat dijadikan sumber primer dalam meneliti sejarah global. Keenam surat kabar tersebut adalah 'Oetoesan Hindia', 'Pantjaran Warta', 'Keng Po', 'Warta Hindia', 'Pemandangan', dan 'Soeara Oemoem'. Kesimpulan penelitian ini adalah pertama, surat kabar dapat dijadikan sebagai sumber primer sejarah global karena berisi tulisan yang merespon dinamika global. Kedua, kriteria surat kabar yang dapat dijadikan sumber penelitian sejarah global adalah surat kabar yang memuat informasi dan opini mengenai perkembangan global.
\end{abstract}

Kata Kunci: Surat kabar langka; Perpustakaan Nasional Republik Indonesia; Sumber primer; Sejarah global 


\section{PENDAHULUAN}

Sejarah global adalah salah satu bidang kajian sejarah yang sedang berkembang pada awal abad ke-21. Sejarah global bukanlah penulisan sejarah yang menulis semua hal tentang apa yang terjadi di seluruh dunia. Sejarah global adalah sebuah pendekatan dalam menulis sejarah. Singkatnya, kita tidak dituntut untuk mengetahui seluruh sejarah di planet bumi. Seorang peneliti sejarah dapat menulis mengenai sejarah satu wilayah atau negara tertentu, namun menekankan pada aspek integrasi dan interkoneksi (Conrad, 2016). Aspek integrasi dan interkoneksi sebagai kata kunci menjadi penting untuk melakukan penelitian sejarah global. Dengan demikian, diperlukan sumber informasi yang memuat koneksi dan integrasi antara satu regional atau negara dengan wilayah lain. Maka, sumber data dan informasi yang dipakai untuk melakukan penelitian sejarah disebut sumber sejarah.

Sumber sejarah merupakan data yang digunakan dalam penulisan sejarah. Sumber sejarah terbagi menjadi dua, yakni sumber primer dan sumber sekunder. Sumber primer merupakan sumber pertama yang diterbitkan atau dikeluarkan pada zaman yang sedang diteliti. Sejarawan sebagai peneliti yang sedang melakukan penelitian mengenai pendirian organisasi Sarekat Islam yang berdiri pada 1916, maka sejarawan harus menemukan dokumen atau tulisan yang diterbitkan pada 1916. Dengan demikian, sumber primer bagi sejarawan adalah sumber yang terbit pada zaman yang sedang diteliti. Salah satu contoh sumber primer yang penting untuk melakukan penelitian sejarah adalah surat kabar. Surat kabar merupakan media informasi dan komunikasi yang digunakan masyarakat dan pemerintah.

Adapun sumber sekunder adalah data yang diterbitkan tidak pada zaman yang sedang diteliti. Biasanya sumber sekunder adalah referensi terbaru yang terkait dengan studi dan penelitian. Ketika kita ingin meneliti mengenai pemikiran politik Soekarno, maka kita mendapatkan banyak buku yang diterbitkan pada tahun 2000-an mengenai Soekarno. Maka buku tersebut masuk ke dalam sumber sekunder karena tidak diterbitkan bersama saat Soekarno hidup.

Berdasarkan metode sejarah, surat kabar merupakan informasi primer karena memuat informasi langsung mengenai masa lampau. Surat kabar memuat banyak informasi historis yang dapat digali, seperti berita telegraf, iklan, opini, dan reportase yang ditulis para koresponden surat kabar. Informasi dalam surat kabar sangat bermanfaat untuk para sejarawan dalam melakukan rekonstruksi terhadap masa lalu. Selain itu, para wartawan, memiliki peran yang sangat signifikan dalam menyampaikan berita kepada publik (Hamami, Sinaga, \& Erwina, 2014). Singkatnya, surat kabar dapat menyediakan data yang kemudian diubah menjadi fakta.

Pada awal abad ke-20, surat kabar sudah banyak bermunculan di Indonesia (Hindia Belanda). Menurut Putra (2019), pada masa ini, pemerintah kolonial juga sibuk dalam melakukan propaganda melalui berbagai media informasi. Menurut Hobbs and McGee (2014), propaganda melibatkan penyebaran fakta, opini, dan ide yang dilakukan dengan disengaja untuk mengubah sikap dan aksi. Sementara menurut Kalçık and Bayraktar (2017), propaganda merupakan usaha untuk, "Mengubah atau mengontrol 
pandangan dan sikap individu atau kelompok [...]."

Surat kabar sudah ada di Indonesia sejak akhir abad ke-18. Surat kabar sudah berkembang pesat pada akhir abad ke-19 dan awal abad ke-20, berkat kemajuan mesin cetak dan kapal uap. Hingga saat ini, Perpustakaan Nasional Republik Indonesia masih menyimpan koleksi surat kabar yang terbit di Indonesia sejak abad ke-19 hingga awal abad ke-21. Institusi ini memiliki surat kabar yang paling tua, yaitu Bataviaasche Koloniale Courant yang diterbitkan di Batavia pada 1810. Selain itu, Perpustakaan Nasional Republik Indonesia juga memiliki surat kabar Java Gouvernment Gazette yang diterbitkan pada masa pemerintahan Thomas Stanford Raffles (1811-1816). Selanjutnya banyak sekali surat kabar, baik berbahasa Belanda, Inggris, Melayu, Jawa, Sunda dan lainlain, yang tersimpan di sana. Banyaknya koleksi surat kabar milik Perpustakaan Nasional Republik Indonesia, maka penelitian sejarah global dapat juga dilakukan pada sumber surat kabar.

Koleksi surat kabar Perpustakaan Nasional Republik Indonesia terbilang sangat lengkap karena perpustakaan ini banyak mendapatkan koleksi warisan dari pemerintah kolonial Belanda. Meskipun secara resmi didirikan pada 1989, sejarah Perpustakaan Nasional Republik Indonesia tidak dapat dilepaskan dari berdirinya Bataviaasch Genootschap van Kunsten en Wetenschappen (BGKW) pada 1799. Berdirinya institusi ini bertujuan membentuk masyarakat pengkaji sains dan seni di Indonesia pada akhir abad ke18. Mereka memiliki koleksi perpustakaan yang sangat lengkap. Maka, banyak koleksi Perpustakaan Nasional Republik Indonesia yang diambil dari koleksi Perpustakaan BGKW.
Penggunaan surat kabar sebagai sumber sejarah global awal abad ke-20 (1900-1945) belum banyak dilakukan para sejarawan. Beberapa sejarawan yang sudah melakukan penelitian sejarah global di antaranya adalah Kees van Dijk dan Dennys Lombard. Namun, penelitian tersebut masih terlalu sedikit jika dibandingkan banyaknya surat kabar Indonesia yang terbit sepanjang awal abad ke-20. Jika kita melakukan penelitian lebih lanjut, maka banyak sekali topik penelitian sejarah global yang dapat dilakukan menggunakan surat kabar. Salah satu topik menarik mengenai sejarah global pada awal abad ke-20 adalah Perang Dunia I (1914-1918) dan Perang Dunia II (1939-1945). Keduanya merupakan perang besar yang melibatkan hampir seluruh dunia. Pada Perang Dunia I dan II, misalnya Inggris mengirim banyak tentara yang terdiri dari tentara Gurkha dan Sikh dari India untuk melakukan peperangan di Timur Tengah hingga Asia Tenggara. Jepang pun menggunakan Sumber Daya Manusia (SDM) dan Sumber Daya Alam (SDA) di Asia Tenggara, seperti Indonesia, Malaysia, hingga Filipina untuk mendukung ekspansi ke Asia Pasifik dan Samudera Hindia. Selain itu, topik sejarah global yang memanfaatkan surat kabar langka, seperti depresi ekonomi 1930-an yang melanda hampir seluruh dunia, tidak terkecuali Indonesia dan negara Asia, seperti India dan Malaysia. Tema mengenai depresi ekonomi sangatlah menarik karena hampir banyak negara tertimpa efek dari depresi ekonomi ini. Dengan demikian, tema tersebut banyak sekali ditemukan di surat kabar sehingga surat kabar dapat menjadi sumber informasi yang sangat berharga bagi penelitian sejarah global. 
Sementara itu, studi mengenai sejarah global masih sangat minim dilakukan di Indonesia. Maka, pustakawan diharapkan mampu membantu para sejarawan dalam meneliti sejarah global melalui analisis terhadap sumber primer sejarah global. Salah satu bahan pustaka, yakni surat kabar memerlukan kajian dan analisis dari pendekatan ilmu sejarah. RobbGrieco (2014) menyatakan bahwa tanpa sumber sejarah, maka sangatlah sulit bagi praktisi untuk berbicara lintas komunitas disiplin dalam membagikan dan memperdebatkan secara produktif pernyataan literasi media hari dan masa depan. Namun, belum banyak penelitian yang dilakukan pustakawan dalam melakukan analisis terhadap sumber primer sejarah. Studi dari Kriswanto et al. (2019) menunjukan bahwa kecenderungan dari kajian peneliti ilmu perpustakaan lebih banyak dilakukan dalam bidang kepustakawanan (librarianship) ketimbang bidang informasi, termasuk subject area database. Penelitian Rushendi (2018) menunjukkan bagaimana pentingnya seorang pustakawan melakukan penelusuran informasi terhadap sebuah subjek. Hal ini menunjukkan bahwa pustakawan membutuhkan kerja sama multidisiplin antara pustakawan dan ilmuwan lain, khususnya sejarawan. Terlebih lagi kemajuan teknologi telah menuntut pustakawan untuk beradaptasi (Mulyadi, Zulkarnain, \& Laugu, 2019). Maka, berdasarkan kemajuan teknologi digital diharapkan pustakawan mampu bekerja sama dengan disiplin ilmu lain.

Salah satu artikel penting yang menggabungkan studi sejarah dan perpustakaan adalah artikel karya Atikah (2018), yang menjelaskan bagaimana cara memandu para sejarawan menemukan sumber penelitian sejarah pada masa
Hindia Belanda. Rujukan ini menjelaskan beberapa sumber referensi, seperti Regeerings Almanak, Volksalmanak, Repertorium van Nederlandsche Indie, dan beberapa indeks khusus lainnya. Berdasarkan artikel tersebut, hubungan antara ilmu perpustakaan dan ilmu sejarah sangat erat dan saling membutuhkan satu sama lain.

Beberapa contoh lain karya multidisiplin antara ilmu sejarah dan perpustakaan adalah karya Nurlidiawati (2014) yang menulis mengenai sejarah perpustakaan yang di Indonesia, dan Saepudin (2016) menulis dengan baik perkembangan perpustakaan dalam kajian sejarah Islam. Kemudian, Brier (2012) mencoba mengkaji hubungan sejarah dan teknologi interaktif. Ketiga rujukan di atas menulis mengenai sejarah perpustakaan dan koleksinya.

Lundemo (2014) pun menuturkan bahwa studi arsip telah mendapatkan perhatian dari berbagai pakar. Berbeda dengan studi mengenai arsip, studi mengenai surat kabar itu sendiri masih belum banyak dilakukan eksplorasi. Padahal, kajian surat kabar sangat penting dalam berbagai bidang. Mahmudi (2014) menulis mengenai bagaimana Monumen Pers Nasional melakukan pelestarian terhadap koleksi surat kabar. Nasriah (2012) melakukan penelitian surat kabar dengan melakukan analisis terhadap konten untuk mengetahui fungsi surat kabar sebagai media dakwah. Kemudian Prihartono (2016), juga melakukan kajian mengenai surat kabar dan konvergensi media dengan studi kasusnya, yaitu surat kabar Solopos.

Namun, penelitian mengenai sejarah koleksi perpustakaan atau koleksi sejarah sangat minim. Maka, diperlukan berbagai pendekatan untuk meneliti bidang 
perpustakaan, misalnya penelitian Rohanda (2013) dan Nurislaminingsih, Erwina, and Rohman (2019). Rohanda (2013) menulis mengenai landasan ilmiah perpustakaan dalam ilmu komunikasi, sedangkan penelitian Nurislaminingsih et al. (2019) mengenai pendekatan arkeologi dalam memetakan koleksi museum.

Sementara itu, pendekatan sejarah masih jarang digunakan untuk mengkaji ilmu perpustakaan dengan analisis sumber menggunakan konteks kesejarahan. Peneliti melakukan penelitian baru dalam bidang ilmu perpustakaan menggunakan pendekatan ilmu sejarah. Penelitian ini dimaksudkan untuk menggabungkan dua disiplin ilmu yang selama ini terpisah agar bermanfaat satu sama lain.

Peneliti melakukan penelitian mengenai peran koleksi surat kabar langka dalam penelitian sejarah global. Adapun tujuan penelitian untuk mengetahui surat kabar agar dijadikan sumber primer dalam penelitian sejarah global, untuk mengetahui kriteria surat kabar yang dapat dijadikan sumber primer penulisan sejarah global, dan mengetahui gambaran spesifik mengenai surat kabar yang dipakai sebagai sumber primer dalam penelitian sejarah global.

\section{METODE PENELITIAN}

Penelitian ini menggunakan penelitian kualitatif deskriptif. Linarwati, Fathoni, and Minarsih (2016) mengatakan bahwa penelitian deskriptif merupakan penelitian yang dilakukan untuk mendeskripsikan suatu fenomena. Adapun objek penelitian mengenai surat kabar langka Indonesia yang dimiliki Perpustakaan Nasional Republik Indonesia.

Pendekatan penelitian menggunakan pendekatan ilmu sejarah karena beberapa alasan. Pertama, untuk menilai apakah sebuah surat kabar layak dijadikan sumber primer dalam penelitian sejarah global sehingga harus dilakukan analisis terlebih dahulu mengenai profil, latar belakang para pemimpin, isi, dan analisis berita yang terkandung di dalamnya. Surat kabar yang diteliti berumur hampir seratus tahun yang lalu sehingga penelitian ini menggunakan pendekatan ilmu sejarah. Kedua, surat kabar yang dimiliki Perpustakaan Nasional Republik Indonesia sangat banyak sehingga tidak mungkin diteliti menggunakan metode statistik.

Penelitian ini dilakukan bulan Maret hingga Desember 2019 di Layanan Surat Kabar Langka Perpustakaan Nasional Republik Indonesia yang berlokasi di Jl. Salemba Raya No. 28 A, DKI Jakarta. Peneliti menggunakan beberapa instrumen penelitian dalam melakukan penelitian ini, seperti buku catatan, buku teks sejarah Indonesia, alat tulis, program komputer Microsoft Word, dan jaringan internet.

Peneliti menggunakan metode deskriptif kualitatif menggunakan pendekatan sejarah dalam menganalisis permasalahan penelitian. Hal ini diteliti menggunakan sumber primer dan sekunder, lalu dianalisis melalui interpretasi. Peneliti dalam penelitian sejarah, memiliki beberapa tahapan yang harus dilalui, di antaranya pencarian sumber (heuristic), verifikasi, interpretasi, dan penulisan. Peneliti dalam melakukan proses heuristic menggunakan berbagai macam koleksi surat kabar yang dimiliki Perpustakaan Nasional Republik Indonesia. Peneliti menentukan lokasi penelitian di Perpustakaan Nasional Republik Indonesia karena perpustakaan ini memiliki dua layanan koleksi surat kabar, yakni surat kabar mutakhir (terbitan lima tahun terakhir) yang berada 
di Perpustakaan Nasional Republik Indonesia Jl. Medan Merdeka Selatan, dan layanan surat kabar langka di Jl. Salemba Raya. Peneliti menggunakan surat kabar yang tersimpan di koleksi surat kabar langka di Perpustakaan Nasional Republik Indonesia Jl. Salemba Raya. Penelitian ini mencoba meneliti sampel 6 surat kabar pilihan yang terbit antara tahun 1900-1950. Peneliti sebelumnya melihat terlebih dahulu 10 surat kabar yang terbit pada awal abad ke-20. Setelah melakukan observasi dan analisis terhadap 10 surat kabar, maka penulis menemukan 6 surat kabar yang terbit dalam skala nasional pada saat itu, di antaranya surat kabar Oetoesan Hindia, Pantjaran Warta, Soeara Oemoem, Keng Po, Warta Hindia dan Pemandangan.

Peneliti setelah melalui tahap heuristic, melakukan verifikasi data yang ditemukan dalam surat kabar. Peneliti melakukan analisis data pada 6 surat kabar untuk melihat apakah data termasuk ke dalam penelitian sejarah global atau tidak. Surat kabar menyimpan banyak sekali informasi mengenai data peristiwa pada masa lampau dari berbagai topik dan pendekatan. Untuk itu, penelitian ini memilih mana data yang dapat menjadi sumber penulisan sejarah global. Pemilihan data sangat penting agar penelitian dapat dilakukan secara efektif dan efisien. Peneliti melakukan hal ini secara teliti dengan membaca referensi mengenai penelitian sejarah global yang diterbitkan di Indonesia atau luar negeri. Setelah peneliti melakukan tahap verifikasi, maka proses interpretasi diperlukan agar peneliti dapat menafsirkan data tersebut. Setelah itu, hasil interpretasi dipaparkan agar dapat dikomunikasikan dengan baik kepada pembaca.

\section{HASIL DAN PEMBAHASAN}

Perpustakaan Nasional Republik Indonesia menyediakan katalog yang tersedia secara manual untuk melakukan proses pencarian data surat kabar. Katalog ini disusun secara alfabetis oleh Endang Sumarsih pada 2018 agar dapat digunakan para pengunjung. Dengan demikian, pengunjung jika ingin mencari nama surat kabar, maka pengunjung harus mencari berdasarkan alfabet depan dari surat kabar tersebut. Selain itu, surat kabar pun disusun berdasarkan kota terbit. Jadi, katalog ini dapat memberikan informasi mengenai surat kabar apa saja yang diterbitkan di Bandung, Semarang, Surabaya, Makassar, dan lain-lain. Katalog ini sangat membantu dalam melakukan pencarian surat kabar.

Informasi dalam daftar surat kabar di antaranya nama surat kabar, periode terbit, kota terbit, bahasa, dan kondisi. Peneliti berikan contoh, ketika kita menemukan surat kabar Aksi dengan nomor panggil Q-404, hal ini menunjukan bahwa bahwa surat kabar tersebut diterbitkan di Yogyakarta pada tahun 1932. Kemudian, katalog ini menunjukan bagaimana kondisi fisik surat kabar yang sedang dicari. Surat kabar dalam kondisi yang rusak tidak dapat dilayankan kepada pengunjung sehingga pengunjung diarahkan untuk mengakses surat kabar yang dilakukan alih media dalam bentuk mikrofilm.

Peneliti kemudian melakukan survei pada beberapa surat kabar masa kolonial Belanda. Hal ini bertujuan mengetahui surat kabar mana yang dapat dijadikan objek penelitian. Maka, peneliti dalam penelitian ini mencoba menelusur surat kabar yang dapat dijadikan sumber primer sebagai penelitian sejarah global. Pada awalnya, survei dilakukan pada 10 surat 
kabar langka di Perpustakaan Nasional Republik Indonesia. Berikut adalah hasil survei yang telah dilakukan.

Tabel 1

Survei pada 10 surat kabar

\begin{tabular}{llll}
\hline No & $\begin{array}{l}\text { Nama surat } \\
\text { kabar }\end{array}$ & $\begin{array}{l}\text { Nomor } \\
\text { panggil }\end{array}$ & $\begin{array}{l}\text { Kelayakan } \\
\text { sumber } \\
\text { primer }\end{array}$ \\
\hline 1 & $\begin{array}{l}\text { Pewarta } \\
\text { Soerabaia }\end{array}$ & Q-325 & - \\
2 & Soeara Oemoem & Q-316 & $\sqrt{ }$ \\
3 & Pemandangan & Q-463 & $\sqrt{ }$ \\
4 & Neratja & Q-67 & - \\
5 & Keng Po & Q-17 & $\sqrt{ }$ \\
6 & Persatoean & Q-247 & - \\
7 & Kaoem Moeda & Q-51 & - \\
8 & Warta Hindia & Q-132 & $\sqrt{ }$ \\
9 & Pantjaran Warta & Q-317 & $\sqrt{ }$ \\
10 & Oetoesan Hindia & Q-96 & $\sqrt{ }$ \\
\hline
\end{tabular}

Sumber: Perpustakaan Nasional Republik Indonesia, 2019

Berdasarkan daftar nama surat kabar di atas, maka didapatkan 6 surat kabar yang layak dijadikan sumber primer penelitian sejarah global. Enam surat kabar tersebut adalah Oetoesan Hindia (nomor panggil Q-96), Pantjaran Warta (nomor panggil Q-317), Warta Hindia, Soeara Oemoem (nomor panggil Q-316), Keng Po, dan Pemandangan (nomor panggil Q-463). Enam surat kabar ini dipilih sebagai sumber primer penelitian sejarah global karena berisikan informasi kejadian dalam kancah internasional, opini atau pandangan mengenai dinamika global. Informasi pertama, berita atau kejadian dalam kancah internasional yang menjadi alasan kuat memilih surat kabar sebagai sumber primer. Surat kabar yang baik untuk penelitian sejarah global tentu saja bukan surat kabar yang bersifat lokal atau terbatas pada daerah tertentu. Surat kabar global harus memiliki koneksi dan jaringan yang cukup luas, seperti surat kabar harus dapat berkorespondensi ke luar negeri dan memiliki koneksi dalam mendapatkan berita internasional. Hal tersebut membuat data dalam surat kabar lebih banyak dan mencakup kejadian di luar Indonesia juga. Kedua, surat kabar merespons kejadian dalam negeri, mengeluarkan opini, dan pendapat mengenai kejadian di luar negeri, seperti Perang Dunia 1 dan Perang Pasifik. Dengan demikian, para jurnalis dan pimpinan surat kabar harus merupakan orang yang memiliki koneksi dan memiliki wawasan luas. Maka, penelitian ini merinci dan menjelaskan secara kualitatif mengenai surat kabar yang layak dijadikan sumber penulisan sejarah global.

Surat kabar Oetoesan Hindia adalah surat kabar yang dimiliki NV Setia Oesaha. Perusahaan ini merupakan badan usaha yang dimiliki seorang Arab Hadhrami, bernama Hassan Ali Soeriati. Sejak abad ke-19, banyak orang Arab Hadhrami yang melakukan migrasi ke Asia Tenggara, khususnya Indonesia. Mereka berperan penting dalam membawa ajaran Tarekat Alawiyah (Alatas, 2014; Athoillah, 2018). Komunitas ini mendiami wilayah yang strategis dalam perdagangan, seperti Jakarta (Batavia), Banten, Cirebon, Semarang, Pekalongan, Surabaya, Makassar, dan lainlain. Kedatangan mereka bertepatan dengan keterbukaan investasi di Indonesia yang dilakukan pemerintah kolonial Belanda. Salah satu bidang bisnis yang populer pada saat itu adalah surat kabar. Surat kabar Oetoesan Hindia adalah salah satu surat kabar yang dimiliki orang-orang Hadhrami.

Selain Hassan Ali Soeriati, tokoh penting dibalik surat kabar Oetoesan Hindia adalah H.O.S. Tjokroaminoto. Dia adalah aktivis pergerakan aktif di Sarekat Islam 
dan menegaskan posisinya sebagai aktivis anti kolonial (Achdian, 2017). H.O.S. Tjokroaminoto adalah seorang aktivis pergerakan yang modern dan mampu menggabungkan nilai Islam dengan modernisasi. Selain itu, Tjokroaminoto pun cukup keras menentang imperialisme dan kapitalisme yang dilakukan kolonial Belanda terhadap Indonesia. Maka, H.O.S. Tjokroaminoto banyak mendapatkan pendukung hingga ke wilayah pedesaan berkat ideologi anti imperialisme dan kapitalisme. Untuk itu, para pendukung Sarekat Islam bertambah lebih banyak berkat figur H.O.S. Tjokroaminoto yang berperan dalam surat kabar Oetoesan Hindia dan terlihat dalam berbagai karya tulisan di surat kabar tersebut. Selain itu, H.O.S. Tjokroaminoto adalah aktivis pergerakan yang berwawasan global, maka surat kabar Oetoesan Hindia meluaskan berita dan opini di kejadian lokal, nasional saja, dan internasional.

Berdasarkan interpretasi atas pembacaan yang dilakukan, Oetoesan Hindia menyimpan banyak sekali data yang dapat digunakan untuk menulis sejarah global. Surat kabar ini dimiliki pengusaha Arab Hadhrami, maka banyak kejadian di Timur Tengah diberitakan surat kabar ini. Dengan demikian, banyak berita atau opini yang mengintegrasikan hubungan antara Indonesia dan Timur Tengah pada awal abad ke-20. Berdasarkan analisis surat kabar Oetoesan Hindia, banyak topik sejarah global yang dapat diangkat sebagai topik penelitian para sejarawan.

Salah satu topik yang sering diangkat Oetoesan Hindia adalah mengenai Perang Dunia 1 (1914-1918) (Supratman, 2017). Tidak diragukan lagi, Perang Dunia 1 merupakan topik favorit untuk menulis sejarah global awal abad ke-20. Perang ini dimulai dari terbunuhnya Pangeran Ferdinand asal Imperium Austria, yang menjadi peristiwa skala global serius untuk diteliti. Ruang lingkup topik Perang Dunia 1 tidak terbatas pada satu negara saja, tetapi sudah berskala global dari mulai Inggris, Prancis, Jerman, Austria, Usmani (Turki), Rusia, India, Australia, dan Selandia Baru. Perang Dunia 1 dapat menjadi topik yang menarik dalam penelitian sejarah global karena skalanya yang global.

Surat kabar Oetoesan Hindia banyak menulis mengenai kabar Perang Dunia 1, di antaranya artikel yang terbit pada 27 November 1914. Artikel tersebut memberitakan mengenai pertarungan Turki dan Rusia di wilayah Erzurum. Hal ini penting ditelaah karena media massa tidak hanya berbicara mengenai fakta dan data, tetapi juga memberikan interpretasi atas suatu kejadian (Fajar \& Restivia, 2011). Berita mengenai Perang Dunia 1 dapat dijadikan sumber primer dalam menulis sejarah global karena berita ini merupakan telegram yang diterbitkan pada tahun 1914. Seperti yang sudah diketahui, sebelum adanya internet, pembuatan pesan telegram melalui telegraf menjadi alat komunikasi yang penting pada Perang Dunia 1. Surat kabar Oetoesan Hindia menjadi salah satu surat kabar yang menerbitkan berita melalui telegram, antara lain berita dari Inggris, Prancis, Jerman, Turki, dan perdamaian antara Turki dan Bulgaria pada 16 Desember 1914 yang.

Selain itu, surat kabar Oetoesan Hindia banyak mengabarkan berita mengenai pandangan para sultan di wilayah Malayu terhadap kondisi Perang Dunia 1. Pada terbitan surat kabar Oetoesan Hindia 2 Desember 1914, memperlihatkan bagaimana para sultan Melayu 
memandang Perang Dunia 1 dan berimbas terhadap masa depan wilayah Melayu.

Selain Perang Dunia 1, data yang dapat diambil dari Oetoesan Hindia untuk penulisan sejarah global adalah kejatuhan Negara Turki-Usmani pada 1923. Oetoesan Hindia banyak memberikan data yang belimpah mengenai Turki karena surat kabar ini dimiliki Arab Hadhrami. Secara kultural, orang Arab Hadhrami banyak memiliki rasa simpati kepada orang Turki Usmani (Supratman, 2016). Hal tersebut terlihat dari berita dan opini yang diterbitkan Oetoesan Hindia. Pada 24 Januari 1923, misalnya Oetoesan Hindia menerbitkan artikel mengenai Moestafa Kemal Pasja (Ataturk). Oetoesan Hindia (1923) menulis bahwa Moestafa Kemal Pasja merupakan penyelamat Turki Usmani karena berhasil mengusir pasukan sekutu (Inggris dan Prancis) dari Turki. Dengan demikian, surat kabar Oetoesan Hindia banyak memberitakan dan menuliskan opini mengenai kejatuhan Turki Usmani dan berdirinya negara Turki.

Surat kabar Oetoesan Hindia menjadi sumber primer yang berharga dalam melakukan penelitian sejarah global. Oetoesan Hindia, surat kabar yang dimiliki orang Arab Hadhrami, maka data yang terdapat dalam surat kabar tersebut berguna untuk menulis sejarah global yang menghubungkan antar dunia Muslim dan Asia dari Jepang, India, Turki, Iran, Afganistan, Malaysia, hingga Indonesia.

Selain itu, surat kabar yang menjadi sumber primer terdapat juga dalam surat kabar Pantjaran Warta, sebagai media propaganda dari Sarekat Islam (SI). Direktur Pantjaran Warta adalah anggota SI yang bernama Goenawan. SI menekankan pada nilai Islam agar tercapainya
Indonesia yang maju. Maka surat kabar ini, banyak menyiarkan berita dari negara muslim dan artikel yang berkaitan dengan ilmu agama.

Surat kabar Pantjaran Warta menjadi sumber bagi penelitian sejarah global karena banyak memuat berita dan artikel opini mengenai negara Muslim. Ketika Negara Usmani masih berdiri, Pantjaran Warta banyak menulis artikel mengenai sejarah Usmani. Pada saat Perang Dunia 1 (1914-1918), Pantjaran Warta juga banyak menulis berita yang terjadi di Negara Usmani. Mereka memberi kabar dan informasi mengenai kejadian yang di Anatolia dan Arab ketika sedang dilanda Perang Dunia 1 (Pantjaran Warta, 1916). Warna ideologi Pantjaran Warta tidak jauh berbeda dari Oetoesan Hindia, maka peneliti tidak akan terlalu banyak memberikan penjelasan tentang Pantjaran Warta. Pada umumnya, kita dapat mengetahui bahwa Pantjaran Warta merupakan sumber yang berharga bagi penulisan sejarah global. Namun, sayangnya surat kabar ini tidak berada dalam kondisi fisik yang cukup baik. Sebagian besar pemustaka atau pengunjung yang ingin membaca surat kabar ini diarahkan membaca koleksi mikrofilm yang berada di Perpustakaan Nasional Republik Indonesia.

Selain itu, surat kabar Warta Hindia terbilang cukup populer pada awal abad ke-20, khususnya ketika Perang Dunia 1. Surat kabar ini diterbitkan di Sumatera Barat. Tentunya surat kabar ini cukup berbeda dengan Oetoesan Hindia dan Pantjaran Warta. Jika kedua surat kabar tersebut cukup keras menentang pemerintah kolonial Belanda, maka Warta Hindia lebih moderat dan bahkan cenderung mendukung pemerintah kolonial Belanda. Dengan demikian, Warta 
Hindia sangatlah bagus dijadikan sebagai sumber primer penelitian sejarah global untuk mengimbangi pemberitaan dan opini yang dikeluarkan Oetoesan Hindia dan Pantjaran Warta. Peneliti dapat menemukan berbagai macam berita mengenai Perang Dunia 1 dalam surat kabar Warta Hindia (Warta Hindia, 1914). Surat kabar ini jelas sekali mengajak rakyat untuk taat di bawah pemerintahan kolonial. Bahkan, peneliti sering menemukan adanya kekaguman para penulis terhadap budaya Eropa dalam artikel yang dimuat Warta Hindia. Dengan demikian, surat kabar Warta Hindia dapat juga dijadikan sumber sejarah global karena sering menyuarakan opini mengenai perubahan yang terjadi di dalam kancah internasional.

Selain Warta Hindia, ada surat kabar Soeara Oemoem yang didirikan pada tahun 1930 di Surabaya. Surat kabar ini pada awal berdiri menggunakan bahasa Jawa agar lebih dapat dibaca dari kalangan Jawa, namun Soeara Oemoem akhirnya diterbitkan menggunakan bahasa Melayu agar dapat dibaca kalangan luas luar Jawa. Salah satu tokoh penting dalam surat kabar ini adalah Raden dr. Soetomo. Dia bertindak sebagai direktur dari Soeara Oemoem, dan memainkan peran penting dalam pergerakan intelektual Indonesia. Raden dr. Soetomo memiliki hubungan yang erat dengan para elite pribumi dan Belanda dari pendidikan dokter yang didapatkan dari School tot Opleiding van Indlandsche Artsen (STOVIA, Batavia). Di STOVIA, Raden dr. Soetomo ikut serta dalam mendirikan organisasi kebudayaan Jawa bernama Budi Utomo (Mukaromah, 2016). Setelah itu, Raden dr. Soetomo diangkat menjadi pengajar di Nederlandsche Indische Artsen School atau NIAS (Sekolah Kedokteran di Surabaya).
Salah satu alasan penting mengapa Soeara Oemoem dapat menjadi sumber primer dan data bagi penelitian sejarah global adalah karena figur Raden $\mathrm{dr}$. Soetomo yang menjadi aktivis global pada awal abad ke-20. Pergaulan Raden dr. Soetomo tidak hanya terbatas pada lingkup nasional, tetapi juga lingkup global. Hal tersebut terlihat ketika Raden dr. Soetomo melakukan perjalanan keliling dunia dan bertemu dengan banyak tokoh, akademisi, dan lain-lain. Surat kabar Soeara Oemoem menerbitkan perjalanan Raden dr. Soetomo keliling dunia, mulai dari Jepang, Singapura, India, Mesir, Belanda, Inggris, Turki hingga Palestina. Perjalanan Raden dr. Soetomo dimulai dari Jepang. Ketika itu, catatan Raden dr. Soetomo mengenai Jepang sangat berharga, misalnya melihat bagaimana kondisi sosial, ekonomi, kebudayaan, hingga kemajuan teknologi yang dimiliki Jepang. Kemudian, peneliti pun melihat rute perjalanan Raden dr. Soetomo menggunakan kapal laut dari Jepang hingga ke Eropa lalu ke wilayah Timur Tengah. Catatan perjalanan menggunakan transportasi kapal laut juga merupakan sumber penelitian sejarah global karena dari hal ini dapat diketahui perjalanan mengelilingi dunia menggunakan kapal laut pada awal abad ke-20.

Selain itu, Soeara Oemoem pun mencatat catatan perjalanan keliling dunia, seperti perjalanan Dr. M. Amir ke Eropa, yang menuliskan dengan baik mengenai perjalanannya mengenai makanan burger, rokok, hingga minuman (Amir, 1936). Catatan seperti itu sangat baik untuk mengetahui bagaimana sudut pandang orang Indonesia mengenai kebudayaan Eropa. Ini tentunya sangat berguna bagi data penelitian sejarah global. Surat kabar Soeara Oemoem pun sering menuliskan 
rubrik bernama "Soerat-soerat dari Negeri Belanda", berisi laporan dari koresponden Soeara Oemoem di Eropa. Para koresponden itu menuliskan mengenai dinamika politik yang terjadi di Eropa. Pada 7 Oktober 1936, misalnya Soeara Oemoem mengeluarkan melaporkan pemberontakan Spanyol yang dipimpin oleh Franco.

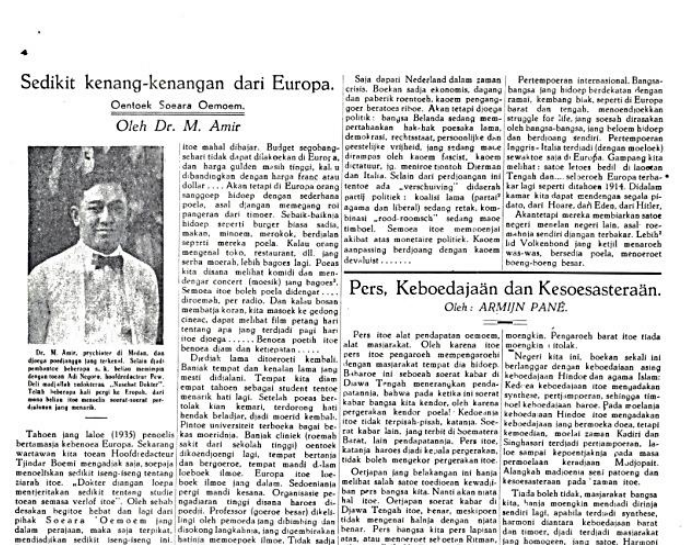

Gambar 1. Artikel di Soeara Oemoem

Sumber: Perpustakaan Nasional Republik Indonesia, 2019.

Alasan lain mengapa surat kabar Soeara Oemoem layak dijadikan sumber penelitian sejarah global adalah adanya simpati Soeara Oemoem terhadap gerakan Pan-Asianisme, yakni gerakan sosial, politik, dan budaya yang terjadi pada awal abad ke-20 dengan tujuan menyatukan seluruh bangsa Asia untuk melawan imperialisme Barat. Gerakan ini lebih banyak diwarnai gerakan intelektual ketimbang gerakan politik. Dengan demikian, visi Pan-Asianisme banyak tersebar melalui tulisan dari para aktivis Asia di seluruh dunia, termasuk tulisan dalam Soeara Oemoem. Selain PanAsianisme, pada awal abad ke-20 pun ideologi nasionalisme mulai berkembang di Indonesia (Fakih, 2014; Utama, 2014).

Surat kabar Soeara Oemoem pun banyak menulis mengenai keadaan ekonomi Jepang pada awal abad ke-20, khususnya sebelum pecahnya Perang
Dunia 2 (1939-1945). Pada Soeara Oemoem tanggal 2 Oktober 1965, misalnya, terdapat artikel mengenai ekspansi ekonomi Jepang ke wilayah Pasifik. Soeara Oemoem sudah memperkirakan tumbuhnya Jepang sebagai ekonomi dunia yang membutuhkan bahan baku dan wilayah untuk memasarkan produknya. Untuk itu, Soeara Oemoem menulis mengenai potensi wilayah di Pasifik, seperti Manchuria dan beberapa wilayah Indonesia yang jauh dari kontrol kolonial Belanda yakni Sumatera, Borneo (Kalimantan), Celebes (Sulawesi), dan lain-lain. Dengan demikian, peneliti melalui Soeara Oemoem dapat mengetahui kejadian berskala global, khususnya di wilayah Samudera Pasifik. Tentu saja data ini sangat penting untuk penelitian karena sejarah global merupakan pendekatan ilmu sejarah yang mengutamakan koneksi dan integrasi antar wilayah.

Selain itu, ada surat kabar Keng Po yang banyak memberitakan pemberitaan global. Surat kabar Keng Po merupakan media yang diterbitkan orang Tionghoa di Indonesia. Surat kabar ini kebanyakan pemberian informasi untuk orang Tionghoa di Indonesia. Pada umumnya, Keng Po berisi artikel dan berita yang ditujukan untuk komunitas Tionghoa, namun tulisan ditulis dalam bahasa Melayu. Hal ini dilakukan agar pembaca Melayu dapat menikmati berita yang dimuat dalam Keng Po.

Surat kabar Keng Po sangat cocok dijadikan sumber penelitian sejarah global karena banyak memberitakan catatan mengenai kejadian yang ada di Cina. Pada awal abad ke-20, Cina sedang mengalami perubahan yang cukup besar dalam bidang politik dan ekonomi. Negara ini menjadi pasar ekonomi dan sumber bahan baku yang penting bagi Inggris. 


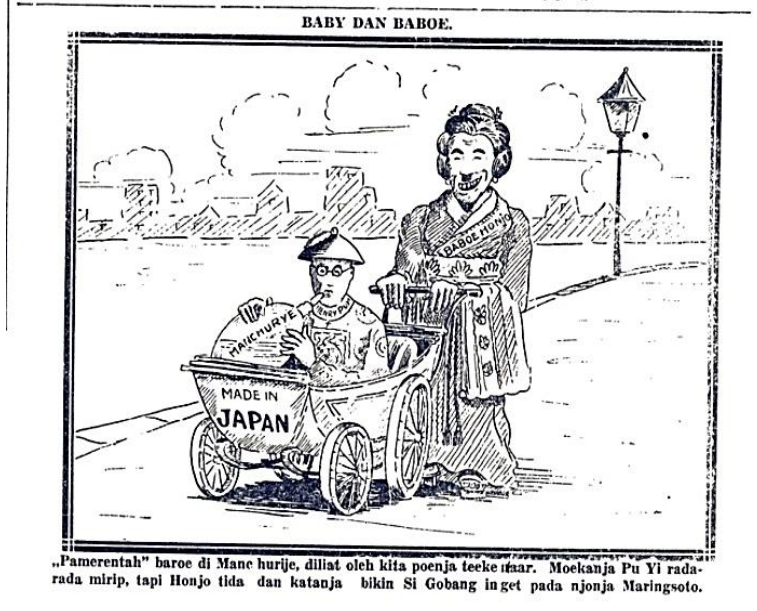

Gambar 2. Karikatur surat kabar Keng Po Sumber: Perpustakaan Nasional Republik Indonesia, 2019.

Cina pun harus menghadapi ekspansi Jepang di Samudera Pasifik. Dengan demikian, kejadian internasional berskala global banyak sekali ditulis dalam surat kabar ini. Salah satu kejadian internasional besar sebelum Perang Dunia II (1939-1945) berlangsung adalah penyerangan Jepang atas Manchuria pada tahun 1931 (Lie, 2012). Dengan demikian, surat kabar ini pada 1930-an banyak memberitakan hubungan antara Cina dengan Jepang, dan Cina dengan negara Eropa (Keng Po, 1932). Banyak berita di Keng Po pun menyoroti kemunculan pemimpin politik di Eropa, seperti Benito Mussolini dari Italia. Untuk itu, Keng Po sangat penting bagi sumber penelitian sejarah global.

Daya tarik Keng Po sebagai sumber penelitian sejarah global terlihat dari berita dan karikatur di dalamnya. Karikatur merupakan media informasi yang disampaikan dalam bentuk gambar, berisikan sindiran terhadap pihak tertentu. Keng Po banyak mengeluarkan karikatur pada tahun 1930-an. Tentu saja, karikatur ini dapat menjadi sumber penelitian sejarah global yang berharga karena karikatur dapat mengetahui bagaimana sebuah surat kabar menyikapi suatu kejadian dalam konteks ruang dan waktu tertentu. Singkatnya, Keng Po merupakan surat kabar propaganda untuk mendukung Cina dalam melawan imperialisme dan kolonialisme Barat dan Jepang. Maka, surat kabar ini layak untuk dijadikan sumber primer dalam menulis sejarah global. Para sejarawan atau peneliti hanya perlu melakukan verifikasi dan interpretasi dengan teliti agar didapatkan fakta yang objektif.

Selain Keng Po, terdapat surat kabar Pemandangan yang dapat dijadikan sumber primer dalam penelitian sejarah. Surat kabar ini merupakan surat kabar yang cukup penting dalam penelitian sejarah global. Pemandangan memiliki keunikan karena banyak mengangkat berita dan artikel mengenai kehidupan perempuan. Surat kabar pimpinan Mohammad Tabrani ini banyak mengulas kehidupan sosial dan budaya perempuan Indonesia dan luar negeri. Untuk itu, Pemandangan dapat menjadi sumber primer dalam penelitian sejarah global.

Beberapa artikel yang ditulis oleh kaum perempuan menggambarkan bagaimana pandangan kaum perempuan Indonesia terhadap perubahan global yang terjadi selama awal abad ke-20. Salah satu penulis perempuan yang aktif mengisi rubrik opini di Pemandangan adalah Maria Ulfa Santoso, Menteri Sosial pada era Kabinet Syahrir II. Maria Ulfa Santoso aktif mengemukakan pandangannya mengenai perempuan dan perubahan global pada tahun 1930-an. Salah satu artikel menarik yang ditulis oleh Maria adalah mengenai obituary Moestafa Kemal Pasja (Ataturk), Presiden Turki pertama. Artikel ini menunjukan bagaimana pandangan perempuan Indonesia mengenai perubahan sosial politik dan kebudayaan di Turki pada masa 
pemerintahan Moestafa Kemal Pasja (Ataturk) (1923-1938) (Santoso, 1938).

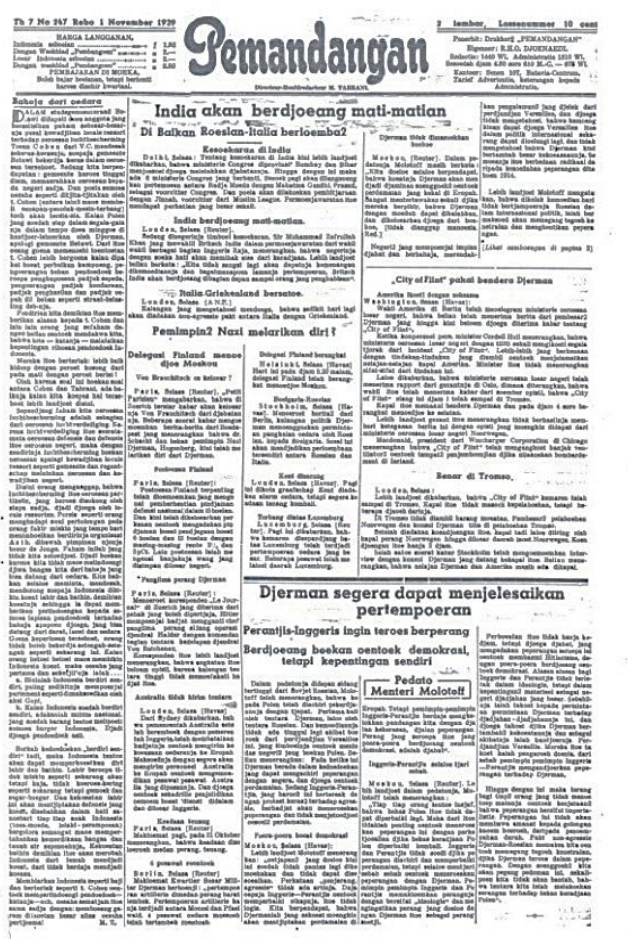

Gambar 3. Surat kabar Pemandangan

Sumber: Perpustakaan Nasional Republik Indonesia, 2019.

Selain memberitakan mengenai pandangan perempuan Indonesia terhadap dunia, Pemandangan pun banyak mengabarkan dan memasang rubrik opini mengenai politik internasional. Pada tahun 1930-an, dunia sedang mengalami perubahan politik. Naiknya Hitler dari Partai Nazi Jerman dan Benito Mussolini di Italia sebagai pemimpin negara telah menciptakan konflik baru di Eropa. Surat kabar Pemandangan pada situasi politik seperti ini banyak mengeluarkan berita mengenai tokoh Eropa dan Amerika Serikat, seperti Hitler, Mussolini, Roosevelt, dan Churchill. Berita mengenai politik internasional tersebut diwarnai foto yang menarik. Dengan demikian, surat kabar Pemandangan merupakan sumber primer yang berharga bagi penulisan sejarah global.

\section{SIMPULAN}

Peneliti dalam mencari data tentang sejarah global melakukan analisis pada 10 surat kabar langka, yang akhirnya terpilih menjadi 6 surat kabar langka. Surat kabar ini ialah Oetoesan Hindia, Pantjaran Warta, Keng Po, Warta Hindia, Pemandangan, dan Soeara Oemoem. Adapun kriteria pemilihan enam surat kabar sebagai sumber primer penelitian sejarah global ialah pertama, surat kabar dapat dijadikan sebagai sumber primer sejarah global karena berisi tulisan yang merespon dinamika global. Kedua, kriteria surat kabar yang dapat dijadikan sumber penelitian sejarah global adalah surat kabar yang memuat informasi dan opini mengenai perkembangan global. Berdasarkan simpulan ini, maka penelitian akan dikembangkan lebih lanjut mengenai analisis dan identifikasi terhadap koleksi surat kabar Perpustakaan Nasional Republik Indonesia, khususnya surat kabar berbahasa daerah, seperti Sipatahoenan (Sunda), Djawi Hiswara (Jawa), dan surat kabar daerah yang terbit di luar Pulau Jawa. Selama ini, penggunaan sumber surat kabar masih terbatas pada terbitan Pulau Jawa.

\section{DAFTAR PUSTAKA}

Achdian, A. (2017). Sarekat Islam sebagai kelanjutan Boedi Oetoemo: H.O.S. Tjokroaminoto dan awal kebangkitan nasional di kota Surabaya 1908-1912. Jurnal Sejarah, 1(1), 30-51. https://doi.org/10.26639/js.v1i1.51

Alatas, I. F. (2014). Pilgrimage and network formation in two contemporary Bā 'Alawī Hawl in Central Java. Journal of Islamic Studies, 25(3), 298-324. https:/ / doi.org/10.1093/jis/etu037 Amir, M. (1936, October 1). Sedikit kenang-kenangan dari Eropa. Soeara 
Oemoem, p. 5.

Athoillah, A. (2018). Pembentukan identitas sosial komunitas Hadhrami di Batavia abad XVIII-XX. Lembaran Sejarah, 14(2), 150-170. https://journal.ugm.ac.id/lembaransejarah/article/view/45437/24444

Atikah. (2018). Sebuah panduan ringkas dalam penelusuran sejarah Indonesia masa Hindia Belanda yang ada di koleksi Perpustakaan Nasional RI. Madika: Media Informasi Dan Komunikasi Diklat Kepustakawanan, 4(1), 94-99.

https://ejournal.perpusnas.go.id/md /article/view/484/455

Brier, S. (2012). History, interactive technology and pedagogy: Past success and future directions. Journal of the Canadian Historical Association, 23(2), 1-20. https://www.erudit.org/fr/revues/jc ha/2012-v23-n2jcha0589/1015787ar.pdf

Conrad, S. (2016). What is global history? Princeton \& Oxford: Princeton University Press.

Fajar, A., \& Restivia, D. Y. (2011). Seputar pemberitaan surat kabar Kompas, Seputar Indonesia dan Media Indonesia terhadap persepsi masyarakat pengguna tabung gas. Jurnal Aspikom: Asosiasi Pendidikan Tinggi Ilmu Komunikasi, 1(2), 171-182. https://doi.org/10.24329/aspikom.v1 i2.16

Fakih, F. (2014). Akar-akar kanan daripada nasionalisme Indonesia: Nasionalisme Jawa dalam konteks kesejarahannya. Lembaran Sejarah, 11(1), 37-50. https://journal.ugm.ac.id/lembaransejarah/article/view/23782/15660

Hamami, T., Sinaga, D., \& Erwina, W. (2014). Perilaku pencarian informasi sebagai sumber gagasan pembuatan berita oleh wartawan Pikiran Rakyat. Jurnal Kajian Informasi E Perpustakaan Perpustakaan, 2(2), 111-120. https://doi.org/10.24198/jkip.v2i2.11 644

Hobbs, R., \&McGee, S. (2014). Teaching about propaganda: An examination of the historical roots of media literacy. JMLE: Journal of Media Literacy Education, 6(2), 56-66. https://digitalcommons.uri.edu/jmle /vol6/iss2/5/

Kalçık, T., \& Bayraktar, Ü. A. (2017). Terror propaganda on social media: Daesh Terrorist Organisation. International Journal of Business and Social Science, $8(9)$,

128-137. http://ijbssnet.com/journals/Vol_8_ No_9_September_2017/14.pdf

Keng Po. (1932, June 9). Soewal Manchurie. Keng Po, p. 3.

Kriswanto, Y. R., Rozanti, D. W., Kusumawardhani, D., Noprianto, E., Erliyana, E. Setiadi, I. T., \& Hanifa, Z. (2019). Kecenderungan topik penelitian di bidang ilmu perpustakaan dan informasi dengan kaidah pendekatan kaidan zipf. Berkala Ilmu Perpustakaan Dan Informasi, 15(1), 114-123. https://doi.org/10.22146/bip.34565

Lie, R. (2012). Reaksi media peranakan terhadap perang Tiongkok-Jepang 1937-1939. Lembaran Sejarah, 9(1), 1-8. https://journal.ugm.ac.id/lembaransejarah/article/view/23766/15647

Linarwati, M., Fathoni, A., \& Minarsih, M. M. (2016). Studi deskriptif pelatihan dan pengembangan sumber daya manusia serta penggunaan metode behavioral event interview dalam merekrut karyawan baru di Bank Mega cabang Kudus. Journal of 
Management, 2(2), $\quad$ 1-8 http:/ /jurnal.unpand.ac.id/index.php /MS/article/view/604/588

Lundemo, T. (2014). Archives and technological selection. Cinemas: Revue d'etudes Cinematographiques Journal of Film Studies, 24(2-3), 17-39. https:/ / doi.org/10.7202/1025147ar

Mahmudi, I. (2014). Pelestarian koleksi surat kabar: Studi kasus di Monumen Pers Nasional (Tesis) [UIN Sunan Kalijaga, Yogyakarta].

http:/ / webcache.googleusercontent.c om/search?q=cache:ppHkNp9he2cJ:di gilib.uin-

suka.ac.id/15156/2/1220010036_babi_iv-atau-v_daftar-

pustaka.pdf $+\& c d=1 \& h l=i d \& c t=c \operatorname{lnk} \&$ $\mathrm{gl}=\mathrm{id}$

Mukaromah, A. (2016). Peran sosial-politik priyayi modern di Surabaya tahun 19001940 (Skripsi) [Universitas Airlangga, Surabaya].

http:/ / repository.unair.ac.id/57926/

Mulyadi, Zulkarnain, I., \& Laugu, N. (2019). Adaptasi pustakawan dalam menghadapi kemajuan teknologi. Berkala Ilmu Perpustakaan Dan Informasi, 15(2), 163-174. https://doi.org/10.22146/bip.39843

Nasriah, S. (2012). Surat kabar sebagai media dakwah. Jurnal Dakwah Tabligh, 13(1), 161-176. https:/ / doi.org/10.24252/jdt.v13i2.30 2

Nurislaminingsih, R., Erwina, W., \& Rohman, A. S. (2019). Pemetaan pengetahuan lokal Sunda dalam koleksi di Museum Sri Baduga. Lentera Pustaka: Jurnal Kajian Ilmu Perpustakaan, Informasi Dan Kearsipan, 5(2), 109-120. https:/ / doi.org/10.14710/lenpust.v5i 2.26426
Nurlidiawati. (2014). Sejarah perkembangan perpustakaan di Indonesia. Khizanah Al-Hikmah: Jurnal Ilmu Perpustakaan, Informasi, Dan Kearsipan, 2(1), 18-27. http://journal.uinalauddin.ac.id/index.php/khizanahal-hikmah/article/view/137/102

Oetoesan Hindia. (1923, January 24). Moestafa Kemal Pasja pahlawan Islam. Oetoesan Hindia, p. 4.

Pantjaran Warta. (1916, January 21). Consulaat generaal Turkye Batavia. Pantjaran Warta, p. 1.

Prihartono, A. W. (2016). Surat kabar \& konvergensi media: Studi deskriptif kualitatif model konvergensi media pada Solopos. Channel, 4(1), 105-116. http://journal.uad.ac.id/index.php/C HANNEL/article/view/4210/2317

Putra, P. (2019). Praktik informasi sebagai upaya propaganda program kolonisasi pada masa Hindia Belanda. Bibliotech: Jurnal Ilmu Perpustakaan Dan Informasi, $4(1)$,

19-34. https:/ / doi.org/10.33476/bibliotech.v $4 \mathrm{i} 1.923$

RobbGrieco, M. (2014). Why history matters for media literacy education. Journal of Media Literacy Education, 6(2), 3-20.

https:/ / digitalcommons.uri.edu/jmle /vol6/iss2/2/

Rohanda. (2013). Landasan ilmiah ilmu informasi perpustakaan dalam perspektif ilmu komunikasi. Jurnal Kajian Informasi \& Perpustakaan, 1(1), 9-20.

https:/ / doi.org/10.24198/jkip.v1i1.95 92

Rushendi. (2018). Keputusan pemustaka dalam penelusuran informasi di Perpustakaan Balai Penelitian Tanaman Rempah dan Obat. Jurnal 
Kajian Informasi \& Perpustakaan, 6(1), 15-28.

https://doi.org/10.24198/jkip.v6i1.14 502

Saepudin, D. (2016). Perpustakaan dalam sejarah Islam: Riwayat tradisi pemeliharaan khazanah intelektual Islam. Buletin Al-Turas: Mimbar Sejarah, Sastra, Budaya, Dan Agama, 12(1), 2544.

https:// doi.org/10.15408/ bat.v22i1.29 27

Santoso, M. U. (1938, November 17).

Kemadjoean perempoean Toerki dari gelap mendjadi terang! Pemandangan, p. 4.

Supratman, F. R. (2016). Before the ethical policy: The Ototman state, panIslamism, and modernisation in Indonesia 1898-1901. Aljamiah: Journal of Islamic Studies, 54(2), 447-475. https://doi.org/10.14421/ajis.2016.54 2.447-475

Supratman, F. R. (2017). Rafet Bey: The last Ottoman consul in Batavia during the first world war 1911-1924. Studia Islamika, 24(1), 33-67. https://doi.org/10.15408/sdi.v24i1.36 84

Utama, W. S. (2014). Nasionalisme dan gagasan kebangsaan Indonesia awal: Pemikiran Soewardi Suryaningrat, Tjipto Mangunkoesoemo dan Douwes Dekker 1912-1914. Lembaran Sejarah, 11(1), 51-70. https://journal.ugm.ac.id/lembaransejarah/article/view/23783/15661

Warta Hindia. (1914, November 19). Turkij. Warta Hindia, p. 1. 